\title{
Biogas Production Optimization from POME by Using Anaerobic Digestion Process
}

\author{
Nazmus Shakib*, Mamunur Rashid \\ Department of Mechanical and Manufacturing Engineering, Faculty of Engineering, \\ Universiti Malaysia Sarawak, 94300 Kota Samarahan, Sarawak, Malaysia
}

\begin{abstract}
The aim of this research is to optimize Biogas production from palm oil mill effluent (POME) with organic loading rate $(O L R)$, carbon-to-nitrogen $(C / N)$ ratio and $p H$ using anaerobic processes. Information on the optimum level of factors that significantly effects on biogas production is not previously searched, and thus optimum inputs level such as $p H, O L R, C / N$ ratio to anaerobic reactor are not available in the published paper. This study explores the potential of POME in anaerobic digestion with the perspective to develop a constructive process to treat POME and it can significantly contribute to biogas production. Design of Experiment (DoE) is used to determine the inputs (OLR, $\mathrm{C} / \mathrm{N}, \mathrm{pH}$ ) for conducting research to achieve outputs (biogas production). Based on Central Composite Design (CCD), 5 levels of inputs for $\mathrm{pH}, \mathrm{C} / \mathrm{N}$, and OLR are obtained. The findings of data analysis from Response Surface Methodology (RSM) shows that pH of 6.9, C/N of 30, and OLR of 6 VSS g/L.d have contributed to obtaining 3.8 L/day biogas production from POME. Treating POME anaerobically has proven to be successful because it is value-effective and environmentally friendly. The consequences of the research outcome in terms of environmental pollution are huge. The study suggests implementing a pilot scale study for producing required data is needed in developing economic scale POME treatment plant.
\end{abstract}

Keywords: Carbon-to-Nitrogen Ratio, Greenhouse Gas, Organic Loading Rate, Palm Oil Mill Effluent, Waste to Energy..

\section{Introduction}

Methane that has been emitted from palm oil mill effluent(POME) is identified as one of the vital source of Potential for Worldwide Warming. It has also been stated in various researches That POME's worldwide methane potential is around 600 million $\mathrm{m} 3$ per annum, and this gas has a GWP which is 25 times higher than carbon dioxide. It has also been stated that methane is a source of heat and energy, which currently appearing as a GWP and contributing to increase climatic change [4]. In biogas, 60 to $70 \%$ is methane gas, which means that biogas is one of the main elements for greenhouse effect. The palm oil sector is one of Malaysia's main sectors and is rising quickly to become a major agricultural industry which contributes to the Malaysian economy. The palm oil industries in Malaysia is the world's second biggest. The total production of crude palm oil is $19,961,581$ tonnes and 17,319,374 tonnes respectively in 2015 and 2016 [11].

The amount of usable resources recovered from POME in methane gas form, clean water, and organic fertilizers are plenty. During the anaerobic digestion of POME, about $28 \mathrm{~m}^{3}$ of biogas per $\mathrm{m}^{3}$

\footnotetext{
* Corresponding author.

E-mail address: nazmusshakib350@gmail.com
}

Manuscript History:

Received 19 July, 2019, Revised 22 September, 2019, Accepted 24 September, 2019, Published 30 September, 2019

e-ISSN: 2289-7771

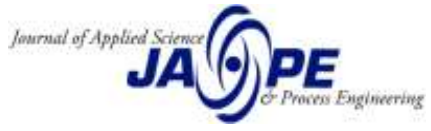


of POME is produced [10]. This study's aim reflects the prospective policies for reducing POME's environmental effects while optimizing POME's biogas production. In this study, laboratory scale anaerobic digester was used for the biogas production.

POME has always been considered an extremely polluting wastewater produced during CPO manufacturing from palm oil factories. POME is a brownish liquid composed of biomass, biochemical oxygen demand (BOD), and chemical oxygen demand (COD). POME is also acknowledged as GWP's accountable source of $\mathrm{CO} 2$ and $\mathrm{CH} 4$ emissions. However, different study results showed that POME's methane potential could be a reliable source of renewable energy rather than carbon emissions [1].

The information mentioned in Table 1.0 showed that methane gas is POME's significant biogas element. This section's review concludes that methane gas potential in POME is significantly high, which shall be captured to achieve sustainability in energy supply.

Table 1. Composition of biogas produced from POME [Shahidul et al., 2018]

\begin{tabular}{|c|c|c|}
\hline Element & Formula & Composition (Vol.\%) \\
\hline Methane & $\mathrm{CH}_{4}$ & $50-75$ \\
\hline Carbon dioxide & $\mathrm{CO}_{2}$ & $25-45$ \\
\hline Water & $\mathrm{H}_{2} \mathrm{O}$ & $2-7$ \\
\hline Oxygen & $\mathrm{O}_{2}$ & $<2$ \\
\hline Nitrogen & $\mathrm{N}_{2}$ & $<2$ \\
\hline Hydrogen Sulphide & $\mathrm{H}_{2} \mathrm{~S}$ & $<2$ \\
\hline Ammonia & $\mathrm{NH}_{3}$ & $<1$ \\
\hline Hydrogen & $\mathrm{H}_{2}$ & $<1$ \\
\hline
\end{tabular}

\subsection{Source and Procedure of Palm Oil Mill Effluent Production}

Three significant activities are accountable for POME generation. POME is primarily produced by new fruit bunch (FFB) sterilization, crude palm oil (CPO) clarification, hydrocyclone separation of crushed shell and kernel combination in the factories [18]. Clarification of extracted CPOs led to approximately $60 \%$ of POME, while FFB sterilization contributed approximately 36\% [3]. The process of hydrocyclone contributed only $4 \%$ [20].

\subsection{Impacts on the environment of Palm Oil Mill Effluent}

Effluent from palm oil mills (POME) has the ability to cause air, water and soil contamination. Untreated POME releases $\mathrm{CH}_{4}$ and $\mathrm{CO}_{2}$ into the atmosphere lead in greenhouse gases (GHGs) being formed. The GHGs can subsidize in increasing The Earth's surface temperature. Increasing temperature will influence the Earth's biotic communities. The increased carbon dioxide $\left(\mathrm{CO}_{2}\right)$ and elevated temperature can be adapted and used by some crops [10]. Meanwhile, some plants failed and unable to survive in extreme conditions. POME is also responsible for increase biodiversity loss due to high level of BOD and COD.

Discharging POME into the river may result in water contamination. POME is acidic, of course. It will decrease the $\mathrm{pH}$ of the water when untreated POME is released into the river [6]. This will make the water inhabitable POME's release into the soil can lead to soil pollution. By leaching heavy metals, POME affects the soil and changes the soil's physicochemical characteristics. 


\subsection{Anaerobic Digestion for Biogas Production}

Anaerobic digestion is one of the appropriate therapy techniques for effluents containing elevated organic carbon concentrations such as effluent from palm oil mills (POME) [1]. It is one of the convenient stabilization methods because it is cost-effective, environmentally friendly, decreases the amount of sludge and is capable of recovering and recovering electricity in the form of methane [15]. This organic process relies on anaerobic microorganisms to digest the biological substance (pollutants) and thereby decrease the effluent BOD. Hydrolytic, acetogenic, acidic and methanogenic microorganisms degrade the complicated polymers of POME [9]. Biogas, consisting of $65 \% \mathrm{CH} 4$, $35 \% \mathrm{CO} 2$, and some trace amounts of hydrogen sulphide, are the end products of anaerobic digestion [5].

\subsection{Problem Statement}

POME is treated with a variety of anaerobic techniques. Mostly biogas production by using lab scale anaerobic reactor. But the optimum level of factors that effects on optimum biogas production from POME by using anaerobic reactor not published. Due to the lack of knowledge in optimizing biogas production from POME, potential agro-based industries are suffering. During the CPO production, $\mathrm{CH}_{4}$ and $\mathrm{CO}_{2}$, which are known as GHG are emitted into the atmosphere. As a consequent, POME becomes a global worming potential due to the emission of $\mathrm{CH}_{4}$ and $\mathrm{CO}_{2}$ gas. The use of environmental-friendly Biotechnology can alter POME's status from waste to energy [WtE]. Treating POME not only emphases on the capturing of biogas but also recover clean water and produce organic fertilizer. Thus, POME can become a precious resource in the future and this study is designed to capture biogas from POME.

\subsection{Research Question}

How to optimize biogas production from POME under the effects of $\mathrm{pH}$, organic loading rate (OLR), and carbon-to-nitrogen $(\mathrm{C} / \mathrm{N})$ in an anaerobic environment? The purpose of this study is to get this issue answered.

\subsection{Objectives}

This study's broad objective is to Optimize Biogas Production from POME by using Anaerobic Digestion Reactor with the aid of OLR, $\mathrm{pH}$, and $\mathrm{C} / \mathrm{N}$ ratio. The wide objective is split into the following particular objectives in order to achieve the objective of this research:

a) Identify the factors such as OLR of VSS, $\mathrm{pH}$ and $\mathrm{C} / \mathrm{N}$ ratio that significantly affect the biogas production from POME.

b) Optimization of factors like OLR of VSS, $\mathrm{pH}$ and $\mathrm{C} / \mathrm{N}$ ratio that effect to biogas Production.

\section{Models to estimate optimum biogas production}

This section presents the models used to estimate biogas production of POME. This model has been used for designing an anaerobic reactor to capture biogas from POME. 


\subsection{Central Composite Design in optimization}

The axial or star point usually denoted as $(\alpha)$ increases the number of levels to 5 levels thereby giving the experimental design flexibility. It allows the experimental designer to determine the factors that affect on response output in experiment. In Central Composite Design (CCD) the minimum numbers of factors it can accommodate including research variables [24].

\subsection{Design of Experiments (DoE) for Model Development}

Design of Experiments (DoE) is used for determining the inputs (OLR, C/N, pH) for conducting research to achieve outputs (biogas production). The range of inputs (as independent variable) is the key factor to ensure the results from inputs are in line with research goal. However, in the current research DOE is used to determine the range of input such as OLR, $\mathrm{C} / \mathrm{N}, \mathrm{pH}$ in producing biogas. The range of OLR 1 -11 VSS g/L.d, pH $5.3-8.4$, C/N 20 - 40 is been determine from the DoE.

Critical Process Parameter (CPP) and Material Attributes (CMAs) mathematical relationships with Critical Quality Attributes (CQAs) are the potential factors for achieving research goal. Fractional factorial 7-level designs with three variables are used in the current research.

\subsection{Experiment Set up for Conducting Experiment Run}

Total five batch reactors each of 5 litter capacity have used to conduct 20 run that reported in. The outputs (biogas) of 20 runs with respect to inputs of three variables. The distribution of biogas outputs from reactors have analyzed by Design Expert software which shows that outputs are normally distributed

\subsection{Input-output variables characterization of biogas production}

The dependent variable is the characterization of biogas in the anaerobic reactor. The inputs used in the reactor during anaerobic digestion are the autonomous OLR, $\mathrm{pH}$ and $\mathrm{C} / \mathrm{N}$ variables.

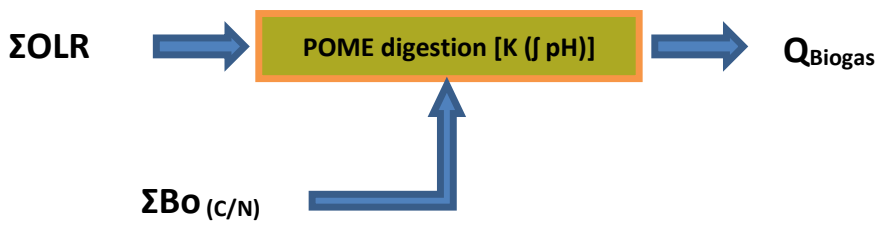

Figure 1. Input output process model POME to biogas $\left(\mathrm{CH}_{4}, \mathrm{CO}_{2}\right.$, and $\left.\mathrm{H}_{2} \mathrm{~S}\right)$

Where, $\mathrm{C} / \mathrm{N}=$ Adjusted by high carbon content Biomass and

$\mathrm{K}=$ Process conversion factor from input to output $(\mathrm{k}<1)$.

\subsection{Method of data collection and analysis}

To accomplish the study objective, quantitative information are collected. Analysis and testing are the technique used to perform information collection. Reactor water samples are gathered to adjust the $\mathrm{pH}, \mathrm{C} / \mathrm{N}$, and OLR. Data are gathered over a period of 30 days biogas every day at the fixed time at 10.00AM. Biogas is collected and measured with use the water displacement method.

The data analysis was done by DOE which include RSM are presented into graphs to show the results of OLR, $\mathrm{pH}$ and $\mathrm{C} / \mathrm{N}$ on biogas production. 


\section{Result and discussion}

\subsection{Determining the factors that significantly effect on biogas production}

The study under this section was to be carried out identify the factors that significantly affect the biogas production from POME. Design Expert (Version - 2018) are used for data analysis. The input factors in this study are $\mathrm{pH}, \mathrm{C} / \mathrm{N}$, and OLR. This experiment is setup to identify inputs which are significant $(\mathrm{p}<0.05)$ and contribute to biogas production. The inputs data were collected from the experiment.

Table 2. Factors that significantly contribute to produce biogas production from POME

\begin{tabular}{|l|l|l|l|}
\hline $\begin{array}{l}\text { Factors } \\
\text { (input } \\
\text { Variables) }\end{array}$ & $\begin{array}{l}\text { p-value of } \\
\text { factors }\end{array}$ & $\begin{array}{l}\text { Significance level of } \\
\text { factors }\end{array}$ & $\begin{array}{l}\text { The Effect Size as Contribution and } \\
\text { biogas production statistics }\end{array}$ \\
\hline $\mathrm{pH}$ & $\mathrm{p}_{\mathrm{pH}}=0.0012$ & $\begin{array}{l}\text { As } \mathrm{P}_{\mathrm{pH}}<.05 ; \\
\text { significant }\end{array}$ & $\begin{array}{l}\mathbf{R}^{2}=0.9994 ; \\
\text { Adjusted } \mathrm{R}^{2}=0.9951 ; \\
\text { Adequate precision }=55.1708 ; \\
\text { Coefficient of Variation }(\mathrm{CV})=0.6194 \% \\
\text { significant }\end{array}$ \\
\hline $\mathrm{C} / \mathrm{N}$ & $\mathrm{p}_{\mathrm{C} / \mathrm{N}}=0.0001$ & $\begin{array}{l}\text { As } \mathrm{P}_{\mathrm{OLR}}>.05 ; \text { Not } \\
\text { significant }\end{array}$ & \\
\hline OLR & $\mathrm{p}_{\mathrm{OLR}}=0.3989$ & \\
\hline
\end{tabular}

Table 2 shows the $\mathrm{p}$-value with respect to Biogas production and $\mathrm{pH}$ is $0.0012(\mathrm{p}<0.05)$, which is significant at 95 percent level; it indicates that $\mathrm{pH}$ has a significant effect on Biogas production from POME. The p-value with respect to Biogas production and $\mathrm{C} / \mathrm{N}$ is 0.0001 ( $\mathrm{p}<.05$ ), which is significant at 95 percent level; it indicates that $\mathrm{C} / \mathrm{N}$ has a significant effect on Biogas production from POME. The p-value with respect to Biogas production and OLR is 0.3989 ( $p>0.05$ ), which is not significant at 95 percent level; it indicates that OLR has effect but not significant to Biogas production from POME.

\subsection{Optimization factors that effect to biogas production}

The findings of data analysis with outputs as response (biogas) shows that the $\mathrm{pH}, \mathrm{C} / \mathrm{N}$ and OLR input variables factors have contributed to biogas production from POME. The input-output data relating to biogas production are estimated by using Design Expert (Version - 2018).

\subsection{Data analysis and findings}

The results of the experiment are analyzed by DoE software and results are presented as 2D and 3D plots, which are presented in Figure 2 and Figure 3. The optimum value of inputs and outputs (biogas) are depicted in Figure 2 and Figure 3. 


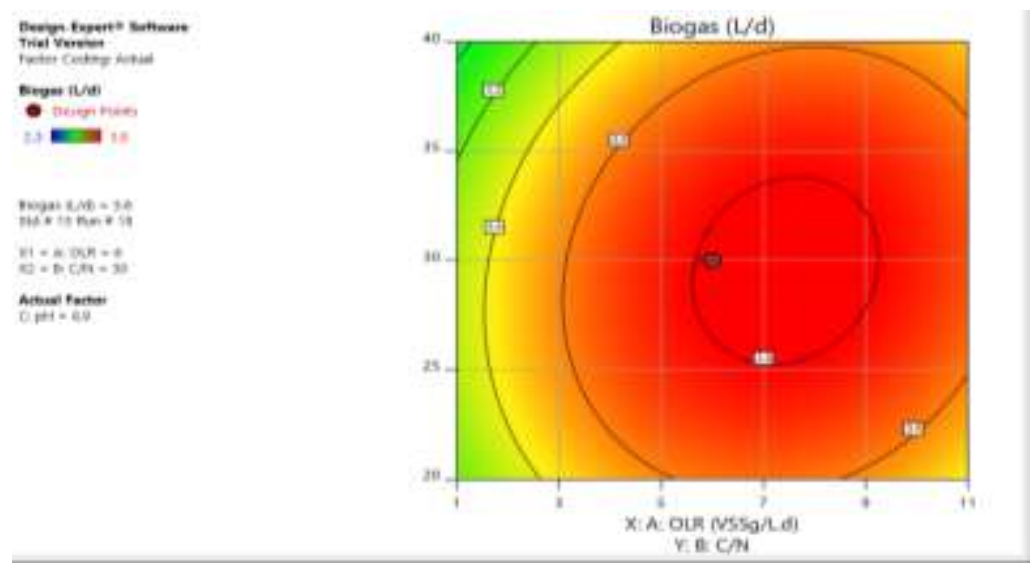

Figure 2. Contour optimization on OLR, $\mathrm{C} / \mathrm{N}$ and biogas

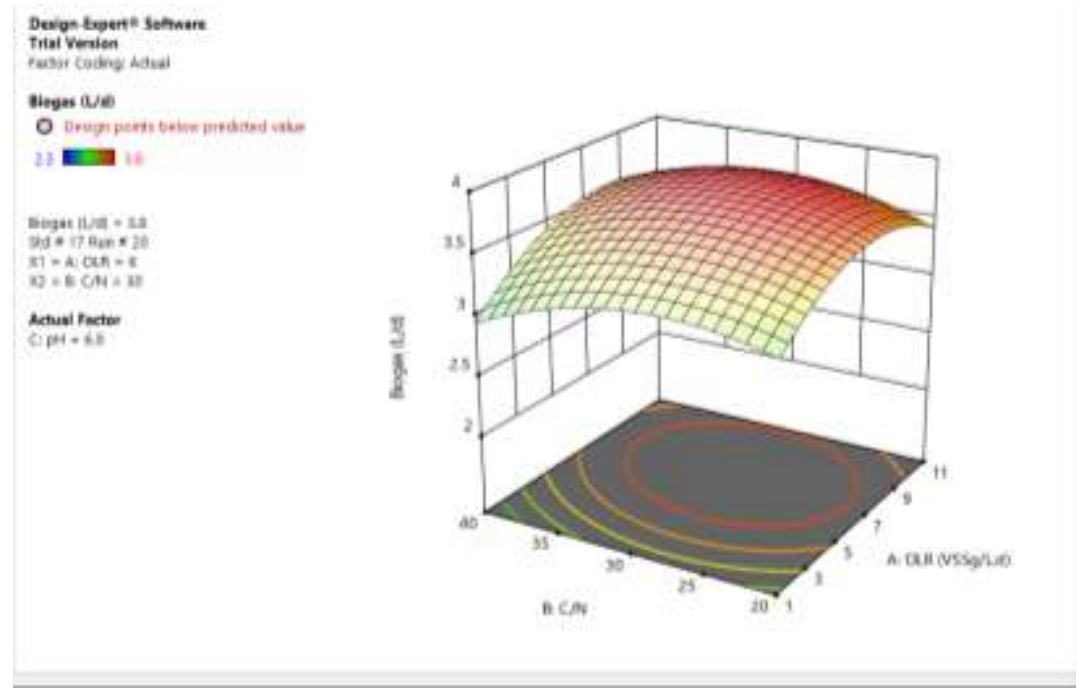

Figure 3. Surface response optimization on OLR, C/N and biogas

Table 2 shows the optimum values required to produce biogas from POME. If anaerobic bioreactor installation and operation with these optimal inputs will produce the optimal amount of biogas. Based on the findings which listed in Table 2, it can be concluded that a bioreactor run with these combinations will contribute to produce optimum level of biogas. In conclusion, it can be stated that the optimum values of factors contributed to biogas production from POME are stated in Table 3. The distribution of model prediction and actual biogas production are presented in Figure 4. 
Table 3. Optimum values of variables and output

\begin{tabular}{|l|c|c|}
\hline Input Factors & Optimum Value & Optimum Outputs as Biogas (L/d) \\
\hline OLR (vssg/L.d) & 6 & 3.8 \\
\hline $\mathrm{C} / \mathrm{N}$ & 30 & \\
\hline $\mathrm{pH}$ & 6.9 & \\
\hline
\end{tabular}

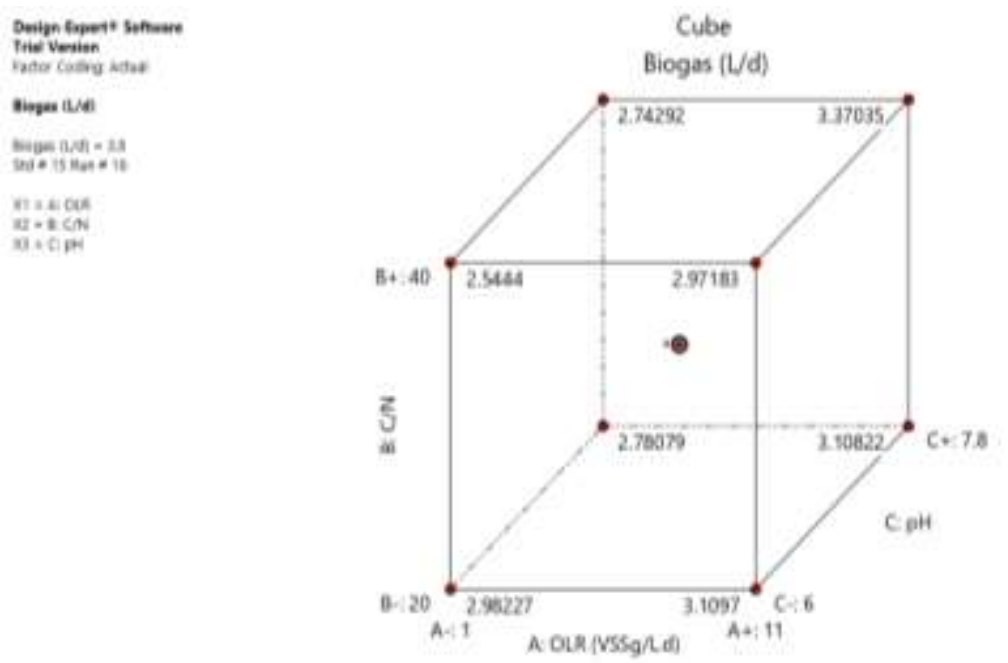

Figure 4. Surface response optimization $\mathrm{C} / \mathrm{N}, \mathrm{pH}, \mathrm{OLR}$ and biogas

The objective of the research is achieved and the research question is replied. The model confirmation was further tested which shows that coefficient of 20 run is 3.81 and standard error is only $0.1133 \%$.

\section{Conclusion}

The result findings demonstrate that anaerobic digestion process is a preferable method optimize the production of POME methane. The anaerobic reactor is configured for hydrolysis at the first stage and acidogenesis. The anaerobic reactor is configured for acetogenesis and methanogenesis in the second stage. It was found that the optimum $\mathrm{pH}$ of $6.9, \mathrm{C} / \mathrm{N}$ of 30 , and OLR of $6 \mathrm{VSSg} / \mathrm{L} . \mathrm{d}$ were able to obtain biogas production of $3.8 \mathrm{~L} /$ day. Different research has verified that biogas waste methane could be captured and used as renewable energy for heat and electricity generation using the WtE notion.

The anaerobic digestion process has the potential to become a leading technology in the recovery of biogas resources from POME. This article shows that a significant role can be played by connecting the energy potential of biogas such if palm oil mill waste reducing the dependence of fossil fuels as well as mitigating climate change. Gradually, the current case study has comprehensive consequences for the greening method of increasing palm oil mill waste worldwide, particularly in rapidly developing Asian economies.

This research is designed to conduct a study to optimize biogas production from POME. Similar studies are reported in many published journals; mostly biogas production by using lab scale anaerobic reactor. But the optimum level of factors that effects on optimum biogas production from POME by using anaerobic reactor not published; in this aspect, this research is novel. This study provide 
additional knowledge for researchers involved in the field of renewable energy production from hazardous POME and other wastewaters.

\section{Acknowledgements}

The authors want to recognize the academic support receive from Prof Shahidul Islam, Eugene Jackson Joy and all the research team members. The authors offer his warm thanks to all academic staff of the Engineering Faculty of Universiti Malaysia Sarawak.

\section{References}

[1] Nurul Adela, B., Muzzammil, N., Loh, S. K. and Choo, Y. M. (2014). Characteristics of palm oil mill effluent (POME) in an anaerobic biogas digester, Asian J. Microbiol. Biotechnol. Environ. Sci., Vol. 16, No. 1, 225-231.

[2] Babaee, A., and Shayegan, J. (2011). Effect of organic loading rates (OLR) on production of methane from anaerobic digestion of vegetables waste, In World Renewable Energy Congress-Sweden; 8-13 May 2011, Linkoping, Sweden.

[3] Choi, W.-H., Shin, C.-H., Son, S.-M., Ghorpade, P. A, Kim, J.-J., and Park, J.-Y. (2013). Anaerobic treatment of palm oil mill effluent using combined high-rate anaerobic reactors, Bioresource Technology, $141,138-144$.

[4] Chen, Y., Rößler, B., Zielonka, S., Wonneberger, A.-M., and Lemmer, A. (2014). Effects of organic loading rate on the performance of a pressurized anaerobic filter in two-phase anaerobic Digestion. Energies, 7, 736-750.

[5] Hosseini, S. E., and Abdul Wahid, M. (2013). Pollutant in palm oil production process, Journal of the Air \& Waste Management Association, Vol. 65, No.7, 773-781.

[6] Lam, M. K., \& Lee, K. T. (2011). Renewable and sustainable bioenergies production from palm oil mill effluent (POME): Win-win strategies toward better environmental protection, Biotechnology Advances, Vol. 29, No. 1, 124-141.

[7] Madaki, Y. S., and Seng, L. (2013). Palm oil mill effluent (POME) from Malaysia palm oil mills : waste or resource, International Journal of Science, Environment and Technology, Vol. 2, No.6, 1138-1155.

[8] Malakahmad, A., Lahin, F. A., and Yee, W. (2014). Biodegradation of high-strength palm oil mill effluent (POME) through anaerobes partitioning in an integrated baffled reactor inoculated with anaerobic pond sludge, Water, Air, \& Soil Pollution, Vol. 225, No.3, 1883.

[9] Shahidul, M.I., Malcolm, M. L, and Eugene, J. J. (2018) Methane production potential of POME : A review on waste-to-energy [MTE ] model, Sci Int, Vol. 30, No. 5, 717-728, 2018.

[10] Shahidul, M. I., Malcolm, M. L., Eugene, J. J., and Mamunur, R. (2018). Optimization of factors affecting biogas production from POME, Sci Int, vol. 30, no. 6, pp. 851-859, 2018.

[11] Najib, M. Z. M., Ujang, Z., Salim, M. R., Ibrahim, Z. and Muda, K.(2016). Bioresource Technology reduction and biofixation of carbon dioxide in palm oil mill effluent using developed microbial granules containing photosynthetic pigments, Bioresour. Technol., Vol. 221, No. 2016, 157-164.

[12] Okonkwo, U. C., Onokpite, E., and Onokwai, A. O. (2018). Comparative study of the optimal ratio of biogas production from various organic wastes and weeds for digester/restarted digester, Journal of King Saud University - Engineering Sciences.Vol. 30, No. 2, 123-129.

[13] Osman, R. M., \& Hamad, M. (2015). Anaerobic digestion of pulping wastewater using up-flow anaerobic sludge blanket (UASB) reactor at mesophilic condition, OnLine Journal of Biological Sciences, Vol. 15, No.3.

[14] Rupani, P. and Singh, R.(2010), Review of current palm oil mill effluent (POME) treatment methods: Vermicomposting as a sustainable practice,World Applied. Sciences Journal, Vol. 11, No. 1, 70-81.

[15] R. A. Alrawi,R.A., Ahmad, A., Ismail, N. and Kadir, M. O. A. (2011). Anaerobic co-digestion of palm oil 
mill effluent with rumen fluid as a co-substrate, Desalination, Vol. 269, No. 1-3, 50-57.

[16] Krishnan, S., Singh, L., Sakinah,M., Thakur, S., Wahid, Z. A. and Sohaili J. (2016).Effect of organic loading rate on hydrogen $\left(\mathrm{H}_{2}\right)$ and methane $\left(\mathrm{CH}_{4}\right)$ production in two-stage fermentation under thermophilic conditions using palm oil mill effluent (POME), Energy Sustain. Dev., Vol. 34, 130-138.

[17] Trisakti, B., Manalu, V., Taslim, I., and Turmuzi, M. (2015). Acidogenesis of palm oil mill effluent to produce biogas: effect of hydraulic retention time and Ph. Procedia - Social and Behavioral Sciences, Vol. 195, 2466-2474.

[18] Rajaletchumy, A.P.V. (2010). Evaluation of palm oil mill effluent (pome) by membrane anerobic system (MAS), Doctoral dissertation thesis, University Malaysia Pahang.

[19] Wang, J., Mahmood, Q., Qiu, J.-P., Li, Y.-S., Chang, Y.-S., and Li, X.-D. (2015). Anaerobic Treatment of palm oil mill effluent in pilot-scale anaerobic EGSB reactor, Biomed Research International, 2015(July), 7.

[20] Wong, Y.-S., Teng, T. T., Ong, S.-A., Morad, N., and Rafatullah, M. (2014). Suspended growth kinetic analysis on biogas generation from newly isolated anaerobic bacterial communities for palm oil mill effluent at mesophilic temperature. RSC Advances, Vol. 4, No. 110, 64659-64667.

[21] Wun, W. L., Chua, G. K., \& Chin, S. Y. (2017). Effect of palm oil mill effluent (POME) Treatment by activated, Journal Clean WAS, Vol. 1, No. 2, 6-9.

[22] ChanY.J., and Chong, M.F. (2019) Palm oil mill effluent (POME) treatment-current technologies , biogas capture and challenges, Green Technologies for the oil plam industry, Springer, Singapore. 71-92

[23] Choy, Y.K. (2016). Can palm oil waste be a solution to fossil fuel scarcity and environmental sustainability? A Malaysian case study provides the answer, In Prreceedings of the $8^{\text {th }}$ International Conference on WAste Management and the Enviornment (WM 2016), 97-108.

[24] Yolmeh, M., and Jafari, S. M. (2017). Applications of Response Surface Methodology in the Food Industry Processes. Food and Bioprocess Technology, Vol. 10, No. 3, 413-433. 